<原 著 $>$

アルコール性肝疾患に括ける肝細胞中間径

フィラメントの形態学的変化

小笠原久隆 土屋崇 大石 裕代 溝呂木及み

八木 茂 宇井忠公柴田 正純森本 晉

須田都三男 永山 和男 田中 照二 堀口 正晴*

要 旨：アルコール性肝疾患における肝細胞中間径フィラメント (IF) の形態学的変化を明ら がする目的で，アルニール性肝疾患10例と対照としてのB型ウイルス性肝疾患 5 例, 正常肘 5 例の生検肝組織を用いて，浸漬 detergent extraction 法により細胞骨格標本を作製し，透過 型電顕で観察した。肝細胞の IF は観察可能で, 正常肝ではIF（直径6〜11nm)はほぼ均等に分 布・配列し， desmosome との結合が確認された。一方，アルュール性肝疾患では，IF の分布は 不均等となり，配列は乱れ，通常径より太い径11〜20nmにおよぶIF が観察された。これらの 変化は小葉中心部優位に障害の強い肝細胞に認められた。 また, IF の Mallory body 形成フィ ラメントへの移行を思わせる所見が観察された．以上の所見は，B型ウイルス性肝疾患には認

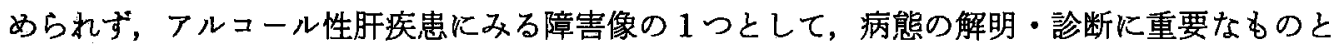
考光られた。

卖引用語： アルコール性肝疾患 肝細胞骨格 中間径フィラメント

Mallory body（アルコール硝子体）

緒言

アルンール性肝障害において，肝細胞骨格に変化を きたすことが知られるよらになってきた。すすなわち， French らは, 形態的観察などから, Mallory body が 異常に凝集した中間径フィラメントから構成されてい ることを提唱しだ). Denk らは Mallory body (MB) が cytokeratin に対する抗体で免度組織学的に染色さ れることを示しだ2. 他方, Baraonaは, フルュール投 与による肝細胞の腫大の原因の 1つとして分泌蛋白の 肝細胞内貯留を指摘し，それは重合チュブリンの減少 によると報告しだ).さらに, Matsuda らは, フルコー ル投与により肝細胞内の重合チュブリン量と微小管の 数が減少し, ゴジ装置の volume and surface density が増大することを示した4). また, Yokoo らは, ア ルコール性肝疾患に和いて, fine filaments が, 多くは アルコール硝子体のみられる肝細胞質に観察されたと 報告している5゙.しかし，臨床例に打けるアルコール性

* 東京慈恵会医科大学第三病院内科 <受付日.61年10月 2 日 $>$
肝疾患の肝細胞骨格，とくに中間径フィラメントの超 微形態学的変化については，な拉十分に観察されてい ない現状と思われる。そこで，生検肝を用いて肝細胞 骨格標本を作製することにより，アルュール性肝疾患 における中間径フィラメントの超微形態学的変化を明 らかにしょらとした。

\section{対象}

アルコール性肝疾患10例，B型ウイルス性肝疾患 5 例, 正常肝 5 例を対象とした. アルコール性肝疾患は, 腹腔鏡下肝生検がなされた例で, 文部省アルコールと 肝研究班の診断基準 ${ }^{6)}$ 従い，その内訳はアルコール 性脂肪肝 2 例, アルコール性肝腺維症 3 例, アルコー ル性肝炎 4 例之肝硬変 1 例であった。正常肝は肝・胆 道系以外の疾患で開腹手術がなされ，肉眼的に肝障害 または限局性小病変が疑われて楔状肝生検がなされた が，組織学的，超微形態学的に正常範囲之考えられた 例である。

万法

生検肝組織は，3 分割し，それぞれ光学顕微鏡標本， 通常電子顕徽鏡標本 (通常電顕標本), 細胞骨格標本の 
作製に供した。

通常電影標本の作製は，従来の方法によった。すな わち，細切した朋組織を1.5\%glutaraldehyde (in 0.1 M cacodylate buffer, $\mathrm{pH}$ 7.3) で 2 時間室温で固定 し，洗浄後， 1 \%osmic acidにて 2 時間後固定した. その後, 上昇ェタノール系列にて脱水し, propylen oxide で置換後, エポキシ樹脂 (Quetol-812)に包埋し た. 超薄切後, 切片を酢酸ウラン・クエン酸鉛による 電子染色を施し, 観察は日立 HS-9透過型電子䫒微鏡 により行った.

細胞骨格標本の作製は，肝組織を約 $1 \mathrm{~mm}^{3}$ 大に細切 し，金属籠に入れ，スターラーで䚓䢁されている0.5\% Triton X-100 (polyethyleneglycol [9 10] p-t-octylphenol）を含む緩衝液（1mM EGTA, 0.5 $\mathrm{mM} \mathrm{MgCl}_{2}$,

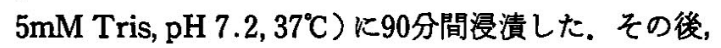
同じ經衝夜で洗浄し $0.1 \%$ ruthenium redを含む $2 \%$ osmic acidにて室温で 3 時間固定を行い, 洗浄後, 2 \%酢酸ウランで30分間ブロック染色を行った. その 後, 前述した通常電顕標本と同様に脱水・包埋し, 光 影用メチレンブルー染色標本にて肝細胞質が淡明化し ている部位をトリミングし, 超薄切を行い, 電子染色 を施し，透過型電顕により $10,15,20 \times 1,000$ 倍で写真 撮影を行い,引伸ばしにて33,000〜100,000倍で観察を 行った.

\section{成 績}

\section{1. 正常肝}

細胞骨格標本における光顕像 ( $1 \mu \mathrm{m}$ 切片, メチレン プルー染色) では, 肝組織塊の周辺部の肝細胞は, 細 胞質が淡明化し，細胞質膜や核膜が不明瞭になってい た (Fig. 1)。このような肝細胞を透過型電䫓で観察す ると, 肝細胞膜は認められず, 細胞質内の可溶性蛋白 や膜系小器官のほとんどは消失し，また核膜も大部分 みられなかった，肝細胞質に相当する部位には，直径 6ー11nm の中間径フィラメントがほぼ均等に分布・配 列していた，中間径フィラメントは，隣接肝細胞間で はデスモゾームに結合し，また残存した膜系小器官と も結合していたが，一方，溶解した膜系小器官が存在 したと思われる部位ではフフィラントの断端が観察 された. 各フィラメントには分岐ないし結合が認めら れた。中間径フィラメントの配列には，とくに極性は 認められず, デスモゾームとの結合部位を除いて明ら かな集合束はみられなかった。 また，直径24－25nmの 直線状ないし軽度湾曲を呈する管状構造物である微小 管が観察された。間径フィラメントと微小管との関

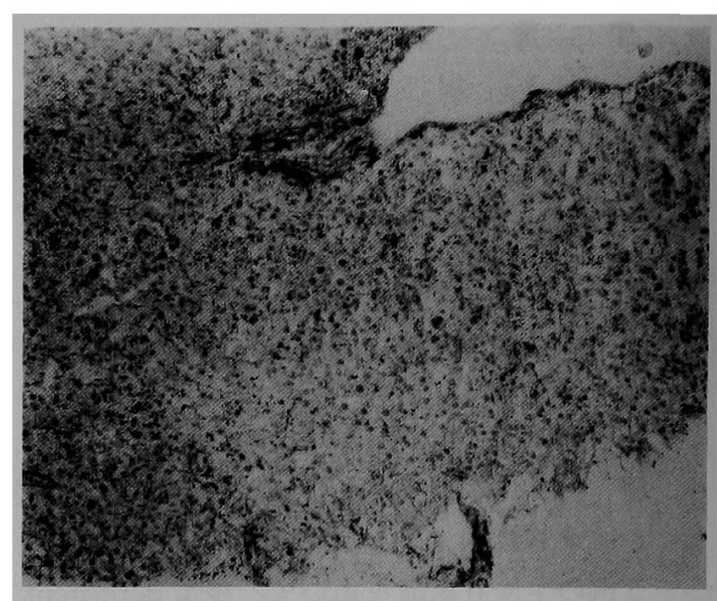

Fig. 1 Light microscopic picture of a piece of normal liver tissue after detergent extraction by immersion method for $90 \mathrm{~min}$. The hepatocytic cytoplasm of peripheral area is clearer than that of central area.

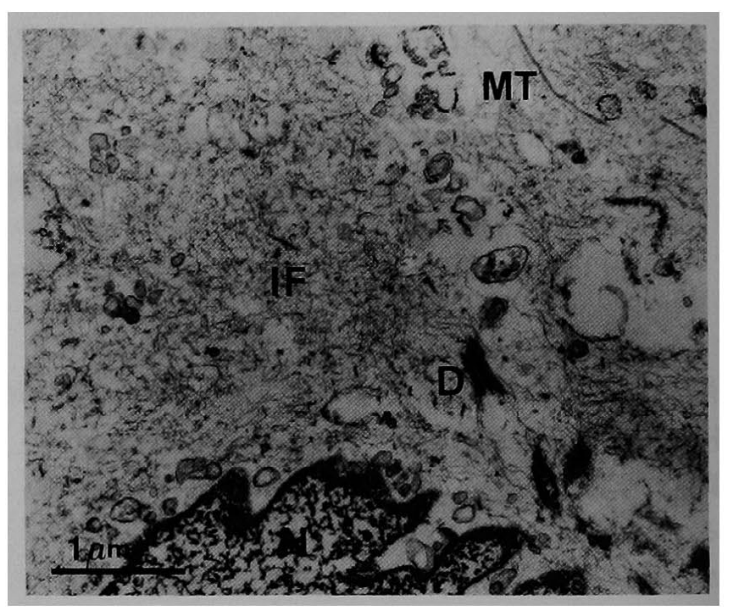

Fig. 2 Electron micrograph of cytoskeleton of normal hepatocyte. Numerous filaments 6 to 11 $\mathrm{nm}$ in diameter (IF) are evenly distributed and part of them connects to desmosomes (D). Some microtubules (MT) are also seen.

係については，2次元の観察では明らかにし得なかっ た. 直径 4〜6nm の microfilament に相応する filamentは明確には認められなかった (Fig. 2).

一方, 肝細胞の通常電顕標本では, 直径 6〜11nmの 中間径フィラメントは, pericanalicular ectoplasm centriole 周辺部でわずかに観察されることもあった がそのほかの部位ではほとんど観察されなかった。 


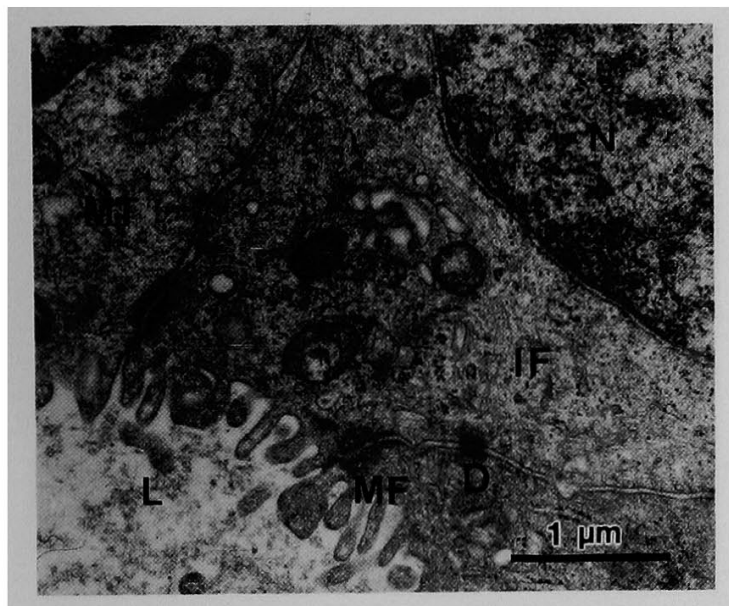

Fig. 3 Electron micrograph of bile-duct cells in normal liver (routine specimen). Some intermediate filaments (IF) can be seen throughout the cytoplasm.

$\mathrm{N}$ : nucleus, $\mathrm{D}$ : desmosome, $\mathrm{MF}$ : microfilaments, MT : microtubules, $L$ : lumen of bile duct

管は肝細胞質全体に観察されたが, centriole 周辺 部や核周囲で目立った. Microfilament は毛細胆管や pericanalicular ectoplasm, 肝細胞膜直下で観察可能 であった。

中間径フィラメントの浸漬 detergent extraction 法 による前後の形態学的变化を明らかにするため, 通常 電顕票本で中間径フィラメントが比較的観察しやすい 胆管上皮細胞について比較を行った，通常電顕標本で は, 膜系小器官や顆粒に乏しい部位で中間径フィラメ ソトが観察され (Fig. 3), 細胞骨格標本では, 中間径 フィラメントの太さや形態に著しい変化は認められ ず，各フィラメントの分岥・結合やデスモザームとの 結合が明確となりより精細に観察可能となった(Fig. 4).

\section{2. アルコール性肝疾患}

細胞骨格標本で中間径フィラメントについて観察す ると，分布密度の高い部分と低い部分が混在し，配列 に乱れが認められた (Fig. 5,6，7）。た，部分的ない し全長にわたり直径11〜20nmに括よぶ太まった中間 径フィラメントが認められた (Fig. 5,6,7). しかし, このような変化を呈した中間径フィラメントもdesmosome との結合が認められたが，部分的に欠くとこ ろもあった (Fig. 6). 以上の变化は, アルコール性肝 炎の全例とアルコール性肝線維症の 1 例において, 小 葉中心部優位に障害の強い肝細胞に認められた。

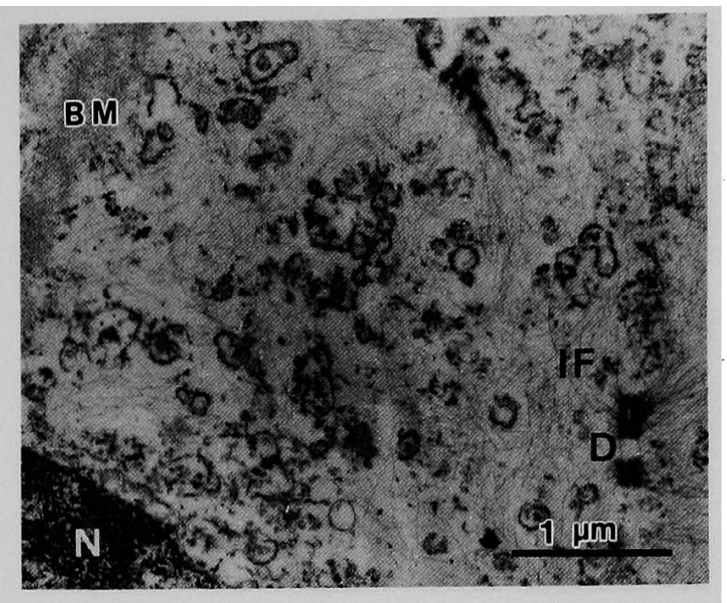

Fig. 4 Electron micrograph of cytoskeleton of a normal bileduct cell. Intermediate filaments (IF) are more clearly seen than those in Fig. 2, and part of them are connected to desmosome (D). MB : basement membrane

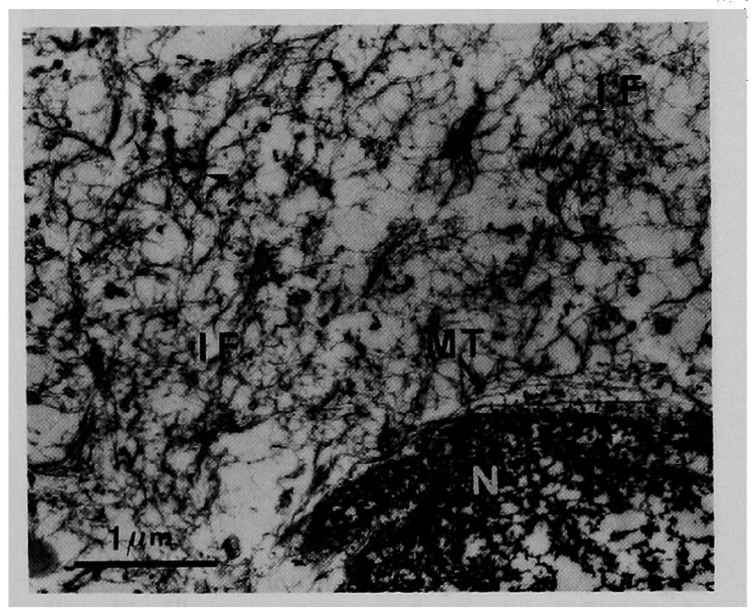

Fig. 5 Electron micrograph of cytoskeleton of hepatocyte in alcoholic liver disease. Filaments 6 to $11 \mathrm{~nm}$ in diameter (IF) are distributed unevenly. Some of IF are thickened up to 11 to $20 \mathrm{~nm}$ in diameter (arrowhead).

MBは，細胞骨格標本で直径10２0nm，長さ約 $100 \sim 300 \mathrm{~nm}$ の比較的均一なフィラメントの集塊とし て認められた。通常にみられる大きさの MBでは, 周 囲の中間径フィラメントとMB形成フィラメントと の連続性が認められたが随所で断絶すしていた（Fig. 7, Fig. 8下方)。小さな MBでは周囲の中間径フィラ メントの MB 形成フィラメントとの移行像と思われ 


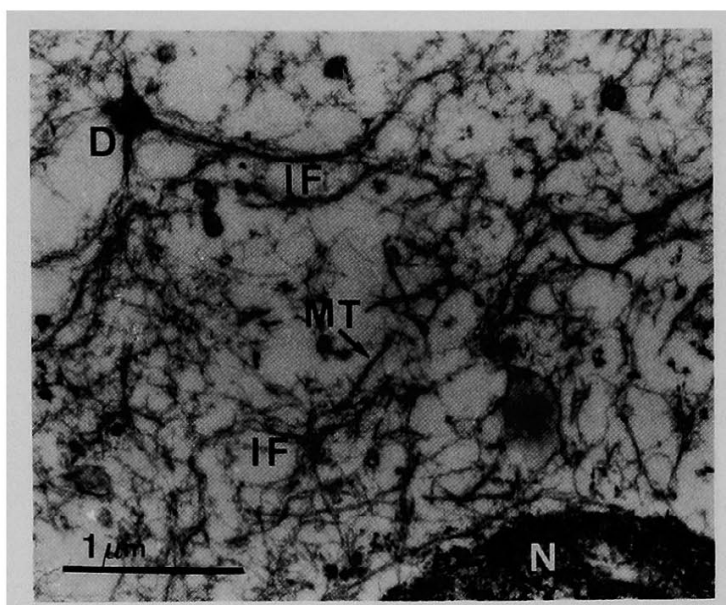

Fig. 6 Electron micrograph of cytoskeleton of hepatocyte in alcoholic liver disease. Disarranged and/or thickened intermediate filaments are observed and connected to desmosome (D).

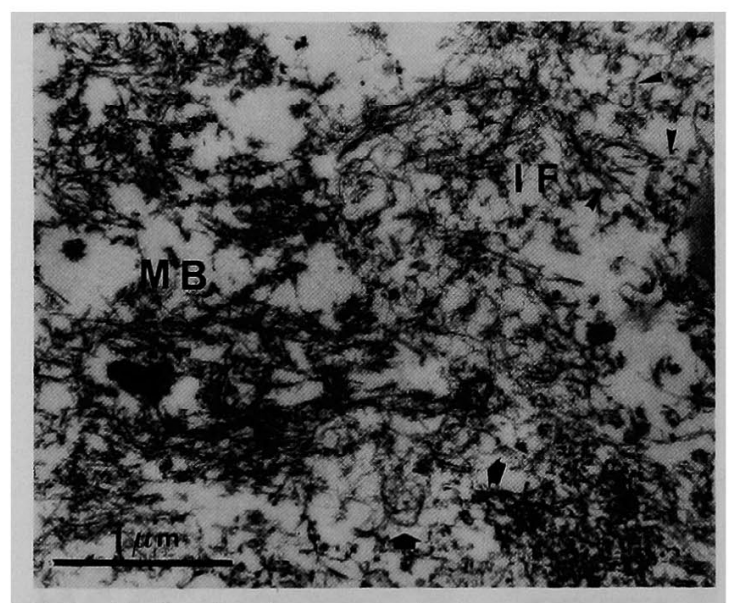

Fig. 7 Another hepatocyte in the same case as in Fig. 6. Intermediate filaments (IF) are thickened (arrowheads) and distributed unevenly near Mallory body (MB). Transitional filaments between IF and component filaments of $\mathrm{MB}$ are indicated by large arrows.

る所見が認められた(Fig. 8右上方, Fig. 9同払大像). MB 周囲の中間径フィラメントK大きな分布・配列の 乱れが認められないこともあった (Fig. 8)が，MBに 瞵接して中間径フィラメントの分布・配列が乱れ太 まった中間径フィラメントが多数認められることも あった (Fig. 7). MB 形成フィラメントの密度は, 周 囲の中間径フィラメントに比較して程度に盖はあるが

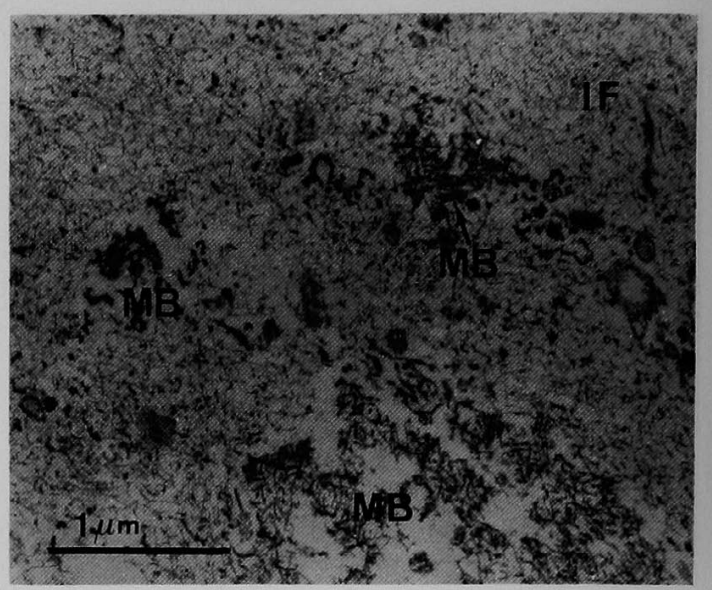

Fig. 8 Electron micrograph of cytoskeleton of hepatocyte in alcoholic liver disease. The continuity of intermediate filaments (IF) to some component filaments of Mallory body (MB) is observed (upper right). On the other hand its continuity is disrupted partly in middle sized MB (lower).

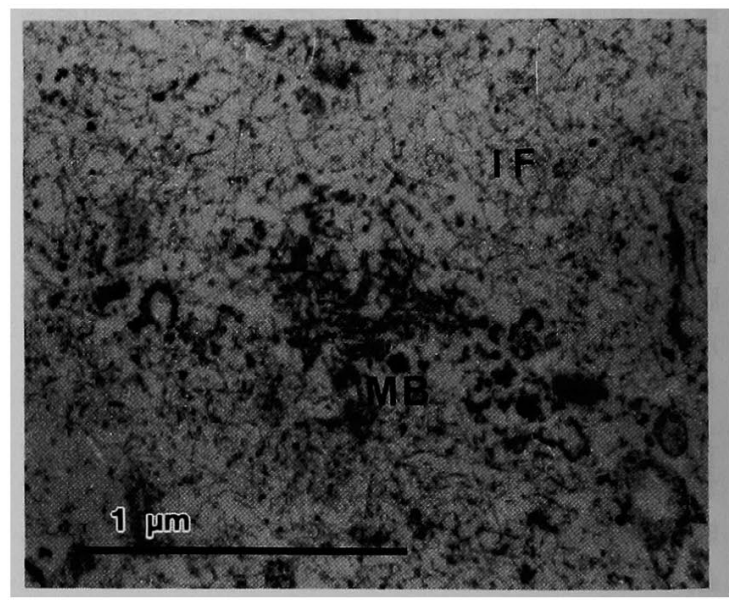

Fig. 9 Magnifying picture of MB showed in the upper right area in Fig. 8.

やや高かった. MBも, 通常, 小葉中心部優位に観察 された。

通常電䫒標本では，肝細胞質に正常肝に比較して中 間径フィラメントが多数観察され，集合束状を呈した り太い径のものも認められた。このような所見は中等 度障害の肝細胞では centriole 周囲や pericanalicular ectoplasm に観察され(Fig. 10), 障害の強い例では細 胞質全体にわたり観察された（Fig. 11）。 


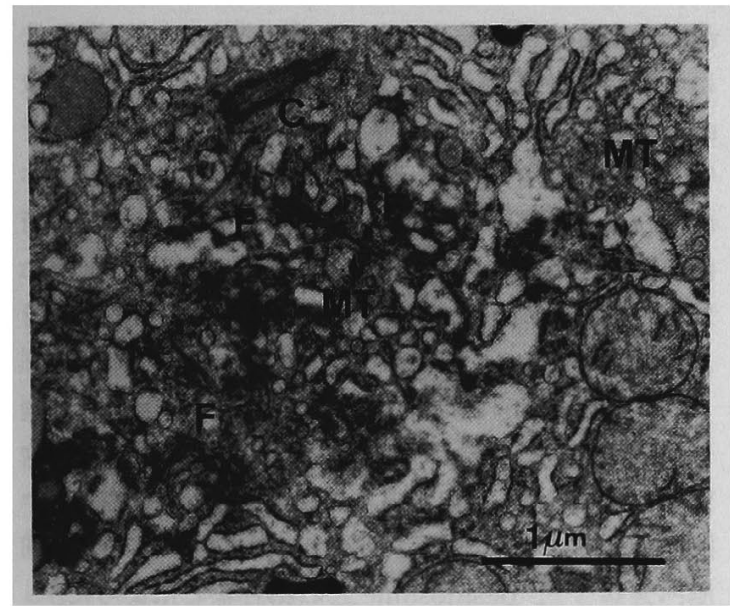

Fig. 10 Electron micrograph of hepatocyte in alcoholic liver disease (the same case as in Fig. 5 , routine specimen). Showing moderate cytoplasmic changes and visible filaments $(F)$ in pericentiole area.

C : centriole, MT : microtubules

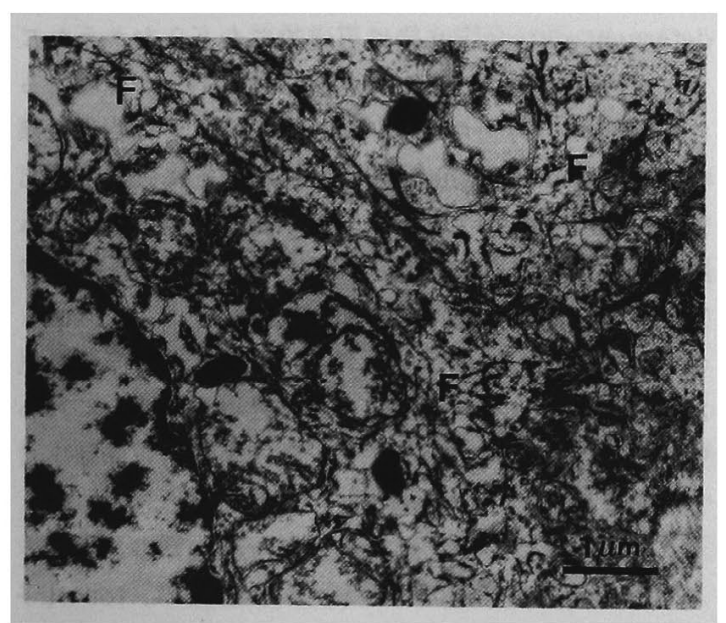

Fig. 11 Electron micrograph of hepatocyte in alcoholic liver disease (the same case as in Fig. 6,7 , routine specimen). Showing severe cytoplasmic and nuclear changes, and thick filaments (F) up to 10 to $20 \mathrm{~nm}$ in diameter.

脂肪滴の出現した肝細胞について細胞骨格標本で観 察すると，中間径フィラメントは脂肪滴により王排さ れており，脂游滴の中に中間径フィラメントは認めら れなかった (Fig. 12).

\section{B型ウイルス性肝疾患}

慢性肝炎例の肝細胞骨格標本をFig. 13に示した

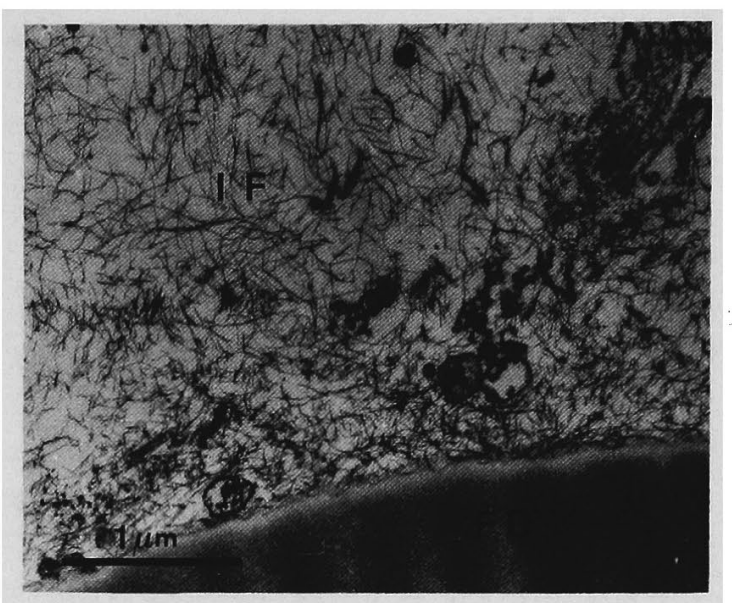

Fig. 12 Electron micrograph of cytoskeleton of hepatocyte in alcoholic liver disease. Intermediate filaments (IF) are compressed by fatty droplet (FD).

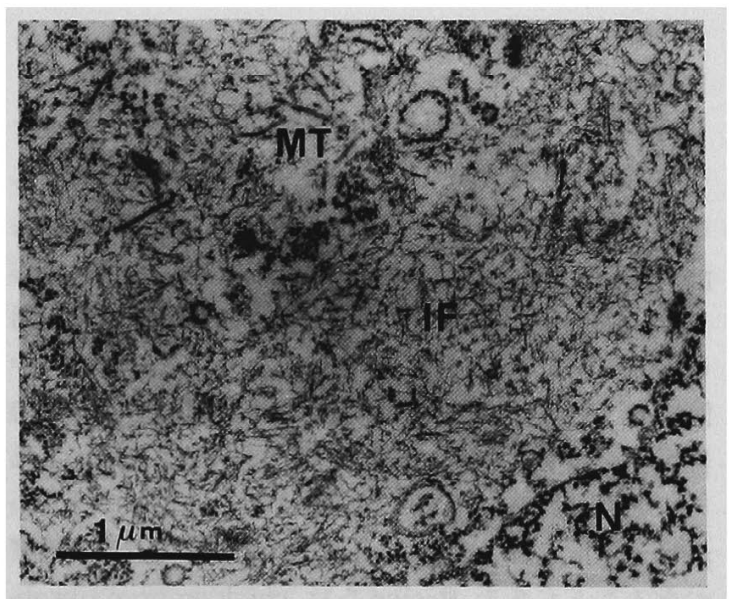

Fig. 13 Electron micrograph of cytoskeleton of hepatocyte in chronic hepatitis (type B). No apparant changes of intermediate filaments (IF) are seen.

MT : microtubules

が, 中間经フィラメントにとくに変化を認めなかった. 肝硬変例について, アルコール性肝疾患例の Fig. 11 と同程度にミトコンドリフの障害された肝細胞の通常 電顕写真を Fig. 14に示したが，アルコール性肝疾患 に認められた太まった中間径フィラメントは認められ なかった。 


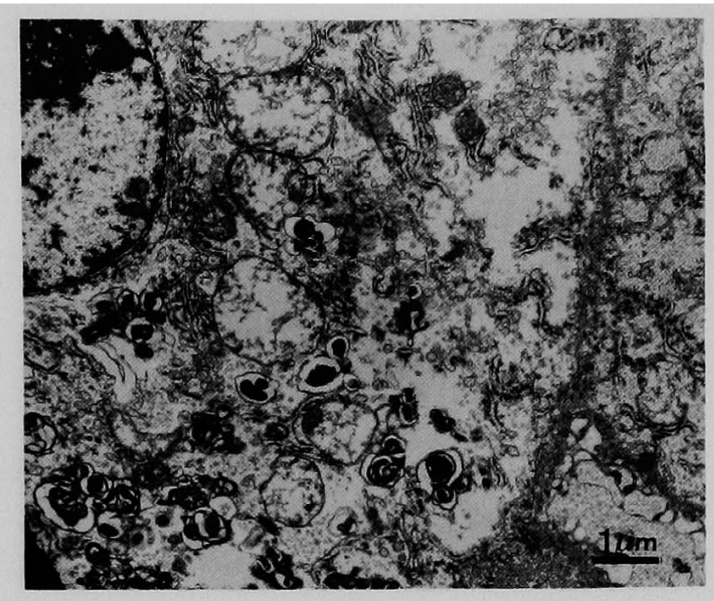

Fig. 14 Electron micrograph of hepatocyte in viral liver cirrhosis (routine specimen). Swelling of mitochondria and lysosomes are conspicuous, but intermediate filaments (IF) are not observed as in alcoholic liver disease. No particular changes of IF were observed in the cytoskeletal specimen of this case.

\section{考察}

肝細胞骨格は，通常電影標本ですある程度観察する ことが可能である. Microfilament は毛細胆管微䄉毛, pericanalicular ectoplasm, 肝細胞膜直下で観察でき， また，钽小管る固定に際し脱重合させない緩衝液を用 い温度に配虑すれば観察することができる。一方，中 間经フィラメントは, 䀒細胞内の豊富な小器官や可溶 性蛋白, クリコーゲン顆粒などに覆い隠されているた めほとんど観察できないが，わずかに小器官に乏しい pericanalicular ectoplasm や centriole 周辺部で観察 できることもある.Brown らは, chick embryo fibroblast $に$ detergent (Triton X-100) を処理して細胞内可 溶性蛋白の抽出 (detergent extraction) を行い, 細胞 骨格を透過型電顕で観察することを可能としだ．肝 細胞については, Jahnは homogenize したラット肝を detergent extraction法により透過型電顕で観察し たタ).さらに, French はラット肝を detergent solution の灌流法により中間径フィラメントを逶過型電顕で観 察し9), Okanoue らは走査型電顕で肝細胞骨格を観察 した ${ }^{10)}$.しかし, 臨床例における中間径フィラメントの 超钽形態学的観察は十分になされておらず，通常電顕 による一部の報告をみるのみである5,11). 本観察では生 検肝組織の中間径フィラメントを観察する目的で, detergent solutionに訮組織を浸漬して detergent
extractionする方法を試みた．French らの肝灌流法 によるラット肝細胞骨格像を指標とし9', detergent solutionをゆるやかに揘䢁して90分間浸漬する条件で 行った. 中間径フィラメントの浸漬 detergent extraction 法による前後の形態像について胆管上皮細胞で 観察したところ，中間径フィラメントの太さや形態に は著しい変化は認められず, より精細に観察可能で あった。

浸漬 detergent extraction 法によるヒト正常肝細胞 骨格の透過型電顕像は，従来報告されたラット肝細胞 骨格の電顕像 ${ }^{9}$ と類似するものであった. 本観察で, 中 間径フィラメントの同定は, フィラメントの直径, 細 胞内分布 ${ }^{12,13)}$, desmosome との結合などによった。

アルコール性肝疾患で肝細胞障害の強い例では, 成 績に示したように，肝細胞中間径フィラメントの分布 は不均等となり, 配列は乱れ, 通常径より太い中間径 フィラメントが認められた，中間径フィラメントの不 均等な分布, 配列の乱れの所見は, 顕著な畽大をきた した膜系小器官による中間径フィラメントの王排が, detergent extraction 後に可逆的にもどらなかったこ とがその原因の 1 つして考えられる. 一方, 太まっ た中間径フィラメントは, MB と同様に, 細胞骨格標 本作製中に detergent solution が機械的に強く作用し て通常径の中間径フィラメントが減少したと思われる 肝細胞においても残存していた。 これらのことから， アルコール性肝疾患に認められた中間径フィラメント の変化は, 変性を受けて太まったり弾力性が減退し, かつ構造的に強固となったものと推察された。これら 中間径フィラォントの変化の一部は, 通常電顕標本で る観察でき, 臨床診断の一助となるものと思われる.

アルコール性肝障害にみられる肝細胞質のフィラメ ントについて文献的にみると, Yokoo らは, tonofilamentに類似した fine filament (直径4 10 nm, 平均 $7.4 \pm 2.1 \mathrm{~nm}$ )の束がおるに たと報告しているず. また, Petersenはアルコール性肝 炎に怙いて肝細胞質内に microfilament が観察され たと述ぺている14).フルコールとは直接の関係はない が, Denk らは, griseofulvin 投与マウスにおいて, MB はその周囲に出現した tonofilament 様構造（直径 7 〜11nm)の束によってしぱしば囲まれていると報告し ている(5).これらの報告にみるフィラメントの直径は, 通常の中間径フィラメントの直径とほぼ同じであり， 本報告で述ぺている太い径のフィラメントについての 記載はみられなかった。しかし、アルコール性肝疾患 
や griseofulvin 投与でフィラメントが通常電顕で観察 されやすくなったことは明らかである。

薬剂やビタミンと中間径フィラメントの変化につい ては, Frankeらは微小管を脱重合させたりMB誘起 剤である griseofulvin 投与マウスにおいて, tonofilamentの量と密度が増加していることを指摘してい る ${ }^{13)}$. 他方，角化細胞において，tonofilament（上皮細 胞の中間径フィラメント）の太まりや keratohyaline body が出現するとされておりり年，また，角化とビタミ ンA欠乏との関係が知られている. 本観察におけるア ルュール性肝疾患で中間径フィラメントの太まりは観 察されたが, keratohyaline body は認められなかった. したがって，本観察結果をビタミンA久乏と直接結び つけることはできないが，その関与は否定できない. また，アルコールの中間代謝産物であるフセトアルデ ヒドなどが中間径フィラメントを変性させることも推 察されるが，今後検討が必要であろう。

MBについて細胞骨格標本で観察すると，Fig. 8に 示したように周囲の中間径フィラメントと MB形成 フィラメントとの移行を思わせる所見が認められた。 さらに, Fig. 7に示したよ5に, MB 周囲の中間径フィ ラメントが太まり，形態的に中間径フィラメントと $\mathrm{MB}$ 形成フィラメントとの移行フィラメントとる思わ れる所見が得られた。 また，MB形成フィラメントの 密度は周囲の中間径フィラメントと比較してやや高 かった.これらの観察結果より，ヒトのアルコール性 肝疾患にみる MBは, 形態学的にみると，中間径フィ ラメントが变性を受けて太まり凝集して形成されたと 推察される. 前述した中間经フィラメントの分布・配 列の乱れや太まりの所見とMB形成との関係につい て，一部には共通の変性過程を有しているかも知れな w.

文献的にMBについてみると, Smuckler は, MBは フィラメント様構造物であり，そのほかの細胞構造物 との関係は示さず, fiberの太さはERのそれと異なっ ていると報告している17). Yokoo らは，MB は線維状 構造物で限界板を持たず，9２1nmの太さとしてい る5). また, Wiggers らはMB を分離して観察すると， 枝分れする filamentで，しばしば管状を示し，約7nm の太さで microfilament と類似していると報告してい る ${ }^{18)}$.さらに, French らは, MB が超微形態像に加兄 て,いろいろなイオン強度, $\mathrm{PH}$ の溶液にも溶解しない ことも中間径フィラメントと類似しており, heavy meromyosin (HMM) を結合しないこと, $2 \mathrm{M}$ guanidine $\mathrm{H}$ Cl に溶解すること，高分子量の蛋白を含 むことなどより，MB は中間径フィラかントの異常な 凝集により形成されると報告している1》。 は griseofulvin 投与マウスの detergent extraction 法 を用いた透過型電顕による観察から，MBは非フィラ メント物質により decorateされた中間径フィラメン トより形成されているとし ${ }^{19)}$, Okanoue らは走査型電 顕による観察から，MBは中間径フィラメントの凝縮 ないし虚脱に由来していると述ぐている20). MB の構 成蛋白について, Franke らは, griseofulvin-treated miceに括いて, MBは prekeratin polypeptide に対す る抗体が結合することを示し12)，また, Denk らはヒト の MBに prekeratin抗体が結合することを示し た2). Greenは，ヒトの MBの polypeptide の分子量 は, 表皮のそれに類似していると述べている ${ }^{16)}$.これら の文献加む, MB は形態学的, 免疫学的, 生化学的 にみても，中間径フィラメントまたはその構成蛋白で あるケラチンが変性して，その結果形成されたすのと いえよう。

以上述べたアルコール性肝疾患に認められた中間径 フィラメントの不均等な分布・配列の乱れと太まり， さらに MBの出現は, 細胞質にお゙いて小器官や核を保 持する構造的役割を果している中間径フィラメントの 障害の表われであり，肝細胞変性として重要なものの 1つと考觉られ。

本論文の要旨は第22回日本肝䐠学会総会において発表し た.

\section{文献}

1) French SW, Davies PL: The Mallory body in the pathogenesis of alcoholic liver disease. In: Alcoholic Liver Pathology, Edited by Khanna JM, Israel Y, Kalant E. House of Lind, Toronto, 1975, p113-143

2) Denk H, Franke WW, Dragosics B, et al: Pathology of cytoskeleton of liver cells : Demonstration of Mallory bodies (alcoholic hyalin) in murine and human hepatocytes by immunofluorescence microscopy using antibodies to cytokeratin polypeptides from hepatocytes. Hepatology 1 : 9-20, 1981

3) Baraona E, Leo MA, Borowsky SA, et al: Pathogenesis of alcohol-induced accumulation of protein in the liver. J Clin Invest $60: 546$ $-554,1977$ 
4) Matsuda Y, Baraona E, Salaspuro M, et al : Effects of ethanol on liver microtubules and Golgi apparatus. Possible role in altered hepatic secretion of plasma proteins. Lab Invest $41: 455$ $-463,1979$

5) Yokoo H, Minick OT, Batti F, et al: Morphologic variants of alcoholic hyalin. Am J Pathol 69: 25-40, 1972

6）武内重五郎, 奥平雅彦, 高田 昭, 他：かが国にお けるフルコール性肝障害の実態. 日消誌 76 ： 2178-2185, 1979

7) Brown S, Levinson W, Spudich J: Cytoskeletal elements of chick embryo fibroblasts revealed by detergent extraction. J Supramol Struct 5 : 119-130, 1976

8) Jahn W: The cytoskeleton of rat liver parenchymal cells. Naturwissenschaften $67: 568,1980$

9) French SW, Kondo I, Irie $T$, et al: Morphologic study of intermediate filaments in rat hepatecyte. Hepatology $2: 29-38,1982$

10) Okanoue T, Ohta M, Fushiki S, et al: Scanning electron microscopy of the liver cell cytoskeleton. Hepatology $5: 1-6,1985$

11）高橋 達, 㭘森昌門, 上村朝輝, 他：アルコール硝 子体周囲に認められる中間径フィラメント束につ いて.「アルコール代謝と肝Vol. 5」藤沢 洌, 木 村和夫, 川瀬治通編, 東洋書店, 東京, 1986, p102 $-109$

12) Franke WW, Denk H, Schmid E, et al : Ultrastructural, biochemical, and immunologic characterization of Mallory bodies in livers of griseofulvin-treated mice. Fimbriated rods of filaments containing prekeratin-like polypeptides. Lab Invest $40: 207-220,1979$

13) Franke WW, Schmid E, Kartenbeck J, et al : Characterization of the intermediate-sized filaments in liver cells by immunofluorescence and electron microscopy. Biol Cellulaire 34: 99 $-110,1979$

14) Petersen $P$ : Alcoholic hyalin, microfilaments and microtubules in alcoholic hepatitis. Acta Pathol Microbiol Scand, Sect A 85 : 384-394, 1977

15) Denk H, Franke WW, Kerjaschki D, et al: Mallory bodies in experimental animals and man. Internat Rev Exp Pathol 20 : 77-121, 1979

16) Green $\mathbf{H}$ : The keratinocyte as differentiated cell type. In: The Harvey Lectures, Series 74. Academic press, New York, 1978/79, pl01-139

17) Smuckler EA: The ultrastructure of human alcoholic hyalin. Am J Clin Pathol 49 : 790-797, 1968

18) Wiggers $\mathrm{KD}$, French $\mathrm{SW}$, French BA, et al: The ultrastructure of Mallory body filaments. Lab Invest 29 : 652-658, 1973

19) Irie $T$, Benson NC, French SW : Relationship of Mallory bodies to the cytoskeleton of hepatocytes in griseofuluvin-treated mice. Lab Invest $47: 336-345,1982$

20) Okanoue $\mathrm{T}$, Ohta M, Ou O, et al : Relationship of Mallory bodies to intermediate filaments in hepatocytes. A scanning electron microscopy study. Lab Invest 53 : 534-540, 1985 


\title{
Ultrastructural changes of intermediate filaments of hepatocyte in alcoholic liver disease
}

\author{
Hisataka Ogasawara, Takashi Tsuchiya, Hiroyo OHIShi, Fumi Mizorogi, \\ Tsutomu Yagi, Tadahiro UI, Masazumi ShIBATA, Susumu Morimoto, \\ Tomio Suda, Kazuo Nagayama, Teruji Tanaka \\ and Masaharu HoRIGUCHI*
}

This study was aimed to clarify the ultrastructural changes of intermediate filaments (IFs) of hepatocyte in alcoholic liver disease. Ten patients with alcoholic liver disease, five patients with normal liver and five patients with viral liver diseases were subjected to this study. Liver biopsies were undergone under laparoscopy or at laparotomy. Small pieces of the liver tissue about $1 \mathrm{cmm}$ in size were soaked in stirring buffer solution containing $0.5 \%$ Triton $\mathrm{X}-100$ for $90 \mathrm{~min}$ at $37^{\circ} \mathrm{C}$. The tissues were fixed with $2 \% \mathrm{OsO}_{4}$ for 3 hours at room temperature and then were dehydrated in ethanols and embedded in epoxy resin. Ultrathin sections were observed with transmission electron microscope. IFs 6-11 nm in diameter were distributed evenly in normal liver. On the other hand IFs were distributed unevenly and some of them were thickened up to $11-20 \mathrm{~nm}$ in diameter in alcoholic liver disease. The continuity of IFs to some component filaments of Mallory body was observed. No apparent changes of IFs were seen in viral liver diseases. It was considered that these findings of IFs were useful for clarifying pathogenesis and diagnosis of alcoholic liver disease.

* Department of Internal Medicine, Daisan Hospital, The Jikei University School of Medicine (Tokyo) 